\title{
MEMBACA PEMIKIRAN HADIS \\ MULLA ALI AL-QARI AL- HIRAWI
}

\author{
H.M. Abduh Wahid \\ Dosen Ilmu Al-Qur'an \& Tafsir \\ Fakultas Ushuluddin dan Filsafat \\ UIN Alauddin Makassar
}

\begin{abstract}
Abstrak
Al-Hirawi, sosok intelektual ensiklopedis yang menghimpun karya-karya para sarjana muslim klasik sebelumnya yang membuktikan kejeniusannya, bahkan Abdur Rahman Syima' menyebutnya sebagai tokoh yang layak digelari pembaharu pada abadnya. ${ }^{1}$ Namun pembacaan pemikiran al-Hirawi dengan kaca mata abad kontemporer dimana perangkat dan metodologi ilmu pengetahuan telah berkembang pesat, sehingga pemikiran klasik al-Hirawi dengan sendirinya termarjinalkan, terkesan rancu dan ditemukan lahan kritikan, padahal sejatinya seorang ilmuwan lebih didasari pada semangat zaman dan ikatan ruang realitas dimana ia hidup. Sehingga ilmu pengetahuan selalu bersifat situasional dan dinamis mengikuti arah ruang dan waktu.
\end{abstract}

Keywords:

Al-Hirawi, Pemikiran Hadis, Tokoh Hadis

\section{PENDAHULUAN}

Sunnah yang disepakati sebagai sumber kedua setelah al-Quran mendapat perhatian ekstra dari para pengkaji ilmu-ilmu keislaman, terlebih pada masa perang saudara yang memunculkan sekian hadis-hadis palsu sebagai afirmasi konsep ideologi masing-masing kelompok. Fokus penelitian para ahli metodologi hadis klasik lebih kepada sanad atau hal ihwal perawi yang dijadikan sebagai parameter keotentikan sebuah hadis dengan sedikit memarginalkan matan yang sejatinya merupakan inti dari proses transmisi hadis. Meskipun pengertian ilmu dirayah dalam ilmu hadis adalah ilmu yang membahas perihal rawi (sanad) dan marwa (matan), ${ }^{2}$ namun penelitian hadis pada sanad mendapatkan porsi paling besar dalam ilmu hadis semenjak terjadinya perang siffin dan jamal. Lain halnya dengan para sarjana modern dan kontemporer yang menyadari urgensi pengembangan kritik matan hadis demi tercapainya pemahaman hadis yang yang bersifat kontekstual dengan memetakan hadis-hadis temporal dan

\footnotetext{
${ }^{1}$ Muhammad Abdurrahman al-Syima', Mulla Ali al-Qari: Fihris Muallafatihi wa Ma Kataba Anhu (Dubai: Tsaqafah wa Turats, 1993), h. 5.

${ }^{2}$ Muhammad Abd al-Mun'im al-Qai'i, Qanun al-Fikri al-Islami: labinat fi bina' al-Manhajiah alIlmiah cet. II (cairo; dar al-Bashair, 2008), h. 173.
} 
universal, syar'iyyah dan gairu syar'iyyah dan lain sebagainya. ${ }^{3}$ seperti usaha Muhammad Abduh, Rasyid Ridha, Muhammad Ghazali dan Yusuf Qardhawi.

Membaca pemikiran hadis al-Hirawi tak semudah membalikkan telapak tangan, kendati karya-karya beliau telah menggurita dan membanjiri pasaran namun sebagian besar karyanya dalam ilmu hadis masih menggunakan metode syarah dan tidak memiliki karya independen dalam mustalah al-hadis itu sendiri. Sehingga penulis merasa kesulitan memetakan pemikiran beliau dengan kitab yang disyarahnya, sebagaimana kitab syarah pada galibnya, yang lebih menekankan pada afirmasi pemikiran status quo. Begitu pula, penulis agak kewalahan dengan keterbatasan referensi yang tersedia dan keterbatasan bacaan penulis terkait dengan al-Hirawi. Penelitian terhadap pemikiran hadis al-Hirawi masih tergolong minim. Sehingga penulis mengakui banyaknya kekurangan dalam makalah ini yang bisa dikembangkan pada tahap selanjutnya.

\section{PEMBAHASAN}

\section{A. Biografi Mulla Ali al-Qari al-Hirawi}

Mulla Ali al Qari dikenal dengan nama al Hirawi, Herat sebuah nama kota besar di Khurasan yang disematkan kepadanya sebagai saksi bisu kelahiran sosok intelektual ensiklopedis yang memiliki kontribusi penting dalam pengayaan khazanah keilmuan Islam. Herat yang juga dinobatkan sebagai pusat peradaban Islam di Asia Tengah ketika itu membentuk jiwa keilmuan al-Hirawi. Pelbagai disiplin ilmu keislaman mendasar khususnya ilmu tajwid digeluti dibawah bimbingan tokoh qiraat agung Muin al-Din al-Hirawi. Namun, gejolak politik di kota tersebut kian memanas, Sultan Ismail ibn Haidar dengan ambisi kuat "meng-syiah-kan" kota Herat sebagai aliran resmi kota dengan sedikit mendesak penduduk mengamini kekafiran khulafa alrasyidun. Para ulama hengkang mencari atmosfir keilmuan yang sejalan dengan konsep kalam masing-masing. Tak terkecuali Mulla Ali al-Qari al-Hirawi dan Makkah menjadi kota tujuannya. ${ }^{4}$

Mekkah sebagai kota kedua al-Hirawi membawa berkah bagi dirinya. Beragam disiplin ilmu dipelajari sampai pada tahap spesialis. ${ }^{5}$ Sehingga tidak mengherankan ketika varian sebutan semisal mufassir, muhaddis, faqih, ushuli, mutakallim, muqri', sufi, adib dan sebagainya dialamatkan pada sosok al-Hirawi. Ia menjadi salah satu tokoh intelektual penting pada abad tersebut. Syekh Sulaiman alMuqri’ al-Masri berdecak kagum pada kapasitas keilmuan yang beliau miliki sebagai tokoh yang mampu menguasai pelbagai ilmu rasional (aqliyah) dan tradisional (naqliyah), begitu pula dengan ilmu dari tanah Arab dan asing (ajam). Al-Hirawi dikenal sebagai ilmuwan yang sangat produktif, al-Bagdadi dalam hadiyat al-arifin menegaskan bahwa karya al-Hirawi berjumlah 107 buku, sedangkan Brookleman

\footnotetext{
${ }^{3}$ Suryadi, Metode Kontemporer Memahami Hadis Nabi; Perspektif Muhammad al-Ghazali dan Yusuf al-Qhardawi (Yogyakarta: Teras, 2008), h. 9.

${ }^{4}$ Uthman Muhammad Na'urah, Syekh Mulla Ali al-Qari, di situs www.marifah.net

${ }^{5}$ Uthman Muhammad Na'urah, Syekh Mulla Ali al-Qari, di situs www.marifah.net
} 
mencatat 185 karya dinisbahkan kepada al-Hirawi. ${ }^{6}$ Di antara karyanya adalah fath alInayah, syarh al-Syatibiyyah, syarh al-Jazariyyah, al-Athar al-Janiyyah, Tarjamah Syekh Abdul Qadir al-Jailani dan dalam Ilmu hadis tercatat al-Hirawi menulis dan mensyarah sejumlah kitab-kitab hadis klasik seperti Syarh Syarh Nukhbat al-Fikr, Mirqat al-Mafatih, Syarh al-Muwatta', Syarh Musnad Abi Hanifah, Jam'u al-Wasail fi Syarh al-Syama'il, Syarh al-Syifa, al-Hirzu al-Samin li al-Husni al-Hasin. Beberapa ahli menegaskan adanya beberapa karya beliau yang hilang tertelan masa seperti Syarh Shahih Muslim, Syarh Jami' al-Shagir dan Syarh al-Mawahib al-Ladunniyah. ${ }^{7}$

Menelisik mozaik kehidupan al-Hirawi, maka dijumpainya sebagai sosok sangat sederhana, wara', tingkat keimanan dan ketakwaan yang mendalam. al-Hirawi harus puas dengan penghasilan jualan buku hasil karyanya sendiri untuk melanjutkan hidupnya. ${ }^{8}$ Diriwayatkan bahwa beliau tiap tahun menulis al-Qur'an dengan khat indah disertai dengan sekelumit penafsiran untuk diperjual-belikan agar kebutuhan primernya tercukupi dari tahun ke tahun. ${ }^{9}$ Berkali-kali ayah al-Hirawi menasehati agar tidak terbuai dengan iming-iming menjadi seorang ilmuwan supaya terhindar dari intervensi penguasa. Mencapai umur dewasa, al Hirawi menjadi seorang intelektual namun godaan keduniaan tidak mendapatkan ruang dalam hati beliau. Al-Hirawi merasa prihatin dengan mereka yang memiliki semangat belajar demi mencapai kemapanan ekonomi dan kehormatan status sosial, ${ }^{10}$ sebagaimana Muhammad Uthman Na'urah kutip dari statemen al-Hirawi sebagai berikut:

"This is how we find students nowadays. They are confused about what they are doing and why. Sometimes they are studying knowledge that has no benefit in this world or the next, just so that they can attain certain spurious objectives, such as getting in with oppressive rulers, gaining high position in society, using flattery to attain ranks, or even just to get food for their bellies".

Al-Hirawi mendapat pencerahan dari guru besar pada abadnya baik di tanah kelahirannya sendiri, begitu pula ulama ternama yang ada di Mekkah. Di antara gurunya adalah Muin al-Din al-Hirawi, Syeikh Ibn Hajar al-Haytami, syekh Ali al-Hindi, Syekh Mair Kelan, Syekh Atiyyah al-Sullami, Syekh Abdullah al-Sindi, Syekh Ahmad al-Din al-Masri. Dan di usianya yang masih tergolong muda al-Hirawi diangkat menjadi seorang Imam dimana pengajiannya dibanjiri oleh jumlah besar jama'ah. Di antara muridnya adalah Syeikh Abd al-Qadir al-Tabari, Syekh Abd al-Rahman al-Murshidi, Syekh Muhammad ibn Furukh al-Mawrubi dan masih banyak lagi. Para sejarawan mencatat bahwa al-Hirawi wafat pada tahun $1014 \mathrm{H}$ di kota Mekkah.

\footnotetext{
${ }^{6}$ Muhammad Abdurrahman al-Syima', Mulla Ali al-Qari: Fihris Muallafatihi wa Ma Kataba Anhu (Dubai: Tsaqafah wa Turats, 1993), h. 4.

${ }^{7}$ Muhammad Abdurrahman al-Syima', Mulla Ali al-Qari: Fihris Muallafatihi wa Ma Kataba Anhu (Dubai: Tsaqafah wa Turats, 1993), h. 4.

${ }^{8}$ Uthman Muhammad Na'urah, Syekh Mulla Ali al-Qari, di situs www.marifah.net

${ }^{9}$ Muhammad Abdurrahman al-Syima', Mulla Ali al-Qari, h. 4.

${ }^{10}$ Uthman Muhammad Na'urah, Syekh Mulla Ali al-Qari, di situs www.marifah.net
} 


\section{B. Sekilas Tentang Kitab Syarh Syarh Nukhbat al-Fikri}

Tradisi meringkas sebuah disiplin ilmu dalam bentuk bait-bait singkat (nadzm) telah membudaya pada komunitas Arab. Keindahan sastra Arab dipertahankan dan diabadikan dari generasi ke generasi baik pada gaya bicara (art of speech) maupun pada penulisan (art of writing). Tak terkecuali, dalam ilmu hadis, ketika para mata cendikiawan klasik tertuju kepadanya sebagai sumber ilmu pengetahuan kedua setelah al-Quran. Pelbagai karya terlahir dalam bentuk nadzam dan ringkasan untuk memudahkan pembaca mengingat dan menghafal kandungan penting dari ilmu hadis tersebut. ${ }^{11}$ Sebagaimana karangan al-Iraqi dalam alfiah-nya dalam bentuk nazam dan nukhbatul fikri karya Ibn Hajar dalam bentuk ringkasan.

Setelah tokoh-tokoh masa formulasi memperkenalkan metodologi dasar ilmu hadis dan mengumpulkan hadis nabi dalam tema-tema tertentu, generasi selanjutnya yaitu pada era afirmasi kembali melanjutkan tongkat estafet dan turut andil berkontribusi dalam keilmuan. namun, secara umum berbeda dengan era formulasi yang berinovasi merumuskan metodologi ilmu hadis. Pada periode selanjutnya lebih mengembangkan tradisi penjelasan (syarah) hadis dan ilmu mustalah hadis dengan mengafirmasi pemikiran yang telah dikonstruksikan sebelumnya. Khalil Ibrahim Qutlai menyimpulkan penyebab mengguritanya tradisi syarah dalam 3 poin, yaitu (1) jerih upaya yang dikerahkan para ulama dalam meletakkan pondasi pemikiran hadis disertai metodologi yang mapan (2) syarah sebagai bentuk penghormatan dan penghargaan atas pengetahuan dan kemulian penghulu mereka (3) dan juga, metode syarah dianggap lebih efisien dalam mencapai tujuan yang diharapkan bersama yaitu generasi sebelum dan setelahnya. ${ }^{12}$ Akan tetapi, metode syarah yang dikembangkan ulama klasik, mendapat sejumlah kritik dari kalangan mutaakhirin yang dianggap ilmu hadis tidak lagi dinamis dan progresif namun ia bersifat stagnan khususnya pada awal abad 11 sampai pada awal abad $14 \mathrm{H}$ hingga disebut sebagai asru al-rukud (periode stagnan) yang ditandai dengan melemahnya inovasi dan kreativitas ulama dan membudayanya tradisi syarah tadi. ${ }^{13}$

Mulla Ali al-Qari salah satu dari mereka yang hidup dalam semangat zaman syarah yaitu di abad 11, sehingga tidak mengherankan jika sebagian karyanya menggunakan metode syarah. Kendati demikian, tidak dapat disangsikan bahwa beliau juga membuahkan sekian karya dari hasil inovasi pemikirannya sendiri, seperti kitab anwar al-Qur'an wa asrar al-Furqan dalam tafsir dan al-Ushul al-Muhimmah fi Husul

\footnotetext{
${ }^{11}$ Penulisan dengan gaya nadzm dan ringkasan menjadi sebuah bakat seni penulisan tersendiri, sebab materi yang kompleks juga berbelit-belit dapat dipadatkan dalam sebuah bait dan diringkas dalam kalimat simple dan jelas.

${ }^{12}$ Khalil Ibrahim Qutlai, al-Imam ali al-Qari wa atsaruhu fi al-Hadis al-Syarif jil. II ( Makkah: Ummul Qura Press, t.th), h. 403-407.

${ }^{13}$ Ahmad Mahram Syeikh Naji, Manahij Muhaddisin min awa'il al-Qarni al-Hadi Asyara ila Awa'il al-Qarni al-Rabi Asyar al-Hijri dalam Mausuah ulum al-Hadis al-Syarif (Cairo: Wizarah alAwqaf, 2007), h. 1004.
} 
al-Mutimmah dalam fiqh ibadat dan al-Masnu' fi ma 'rifat al-Hadis al-Maudhu' dalam ilmu hadis, dan lain sebagainya.

Kitab Syarh Syarh Nukhbat al-Fikri merupakan syarah salah satu karya monumental Ibn Hajar al-Asqalani yaitu Nuzhat al-Nazar yang merupakan ringkasan dari sekian karya mustalah hadis yang tercipta pada abad sebelumnya. Syarh syarh milik al-Hirawi ditulis di penghujung akhir hayatnya, yakni pada tahun $1006 \mathrm{H}^{14}$ Metode penulisan syarah kitab yaitu dengan memaparkan matan nukhbat al-fikri dan nuzhat al-nazar baik per frase maupun per kalimat kemudian dianalisis secara parsial. Al-Hirawi menegaskan faidah syarah itu sendiri dalam 3 poin (1) menjelaskan kekaburan dhamir (tafkik al-dhamir) (2) mengembangkan dan menjawab pertanyaan lanjutan (jawab su'al al-sani), dan (3) menganalisis matan (i'rab al-matan). ${ }^{15}$ Keistimewaan Syarh syarh milik al-Hirawi adalah penguasaan dan kekayaan literatur disertai komparasi pemikiran hadis para sarjana klasik pada generasi sebelumnya. Nampak jelas dari kitabnya pemikiran beliau yang mumpuni dalam ilmu hadis dan unggul pada masanya. Sebagaimana layaknya kitab syarah ulama lainnya, kitab Syarh Syarh ini masih didominasi dengan analisis kebahasaan baik sisi semantik matan maupun dari sisi sintaksisnya, ${ }^{16}$ al-Hirawi dalam banyak kesempatan membumbuhi karyanya dengan komparasi konstruk metodologi hadis tokoh empat mazhab fiqh, meski sesekali terjebak dalam nalar fanatisme sektarian ketika mengafirmasi pemikiran hadis abu hanifah. Begitu pula al-Hirawi sesekali ber-istisyhad (berdalih) dengan ayat al-Quran dan hadis-hadis Nabi dan menguatkan dengan sejumlah syair.

Belum diketahui jelas motivasi al-Hirawi menuliskan pelbagai karya syarah kitab hadis, termasuk syarh syarh milknya. Namun dalam kitab Mirqat al-Mafatih Syarah Misykat al-Masabih secara implisit dinyatakan adanya dominasi mazhab syafi'iyah dalam syarah kitab untuk menguatkan aliran pemikiran berasaskan mazhab Syafi'iyah sebagai berikut:

mayortitas pensyarah (Syurrah) berasal dari mazhab Syafi'i. merka menganalisis permasalahan dalam sebuah kitab dengan perangkat metodologi ala Syafi'iah dan menegaskan bahwa hanafiyah adalah ashab al-ra'yi (rasional) dan menduga mazhab hanafi tidak menjadikan hadis sebagai hujjah bahkan tidak menempuh proses transmisi dan periwayatan hadis dari dulu sampai sekarang, padahal

\footnotetext{
${ }^{14}$ Mulla Ali al-Qari, Syarh Syarh Nukhbat al-Fikri fi Musthalah Ahli al-Atsar (Maktabah Misykat al Islamiyah), h. 202.

${ }^{15}$ Mulla Ali al-Qari, Syarh Syarh Nukhbat al-Fikri fi Musthalah Ahli al-Atsar (Maktabah Misykat al Islamiyah), h. 11.

${ }^{16}$ Contoh analisis kebahasaan al-Hirawi sebagai berikut:

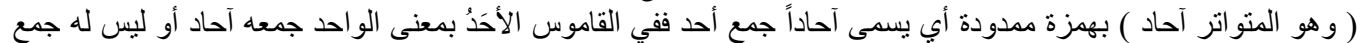

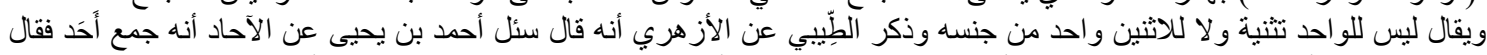

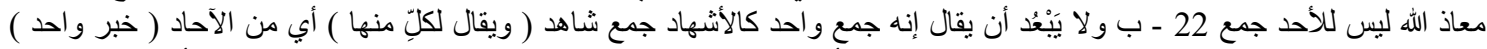

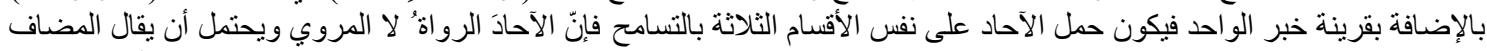
محذوف في الكلام أي خبر آحاد
} 
sangat nyata mereka mengedepankan hadis lemah (dhaif) atas analogi-deduktif (qiyas) yang justru memperburuk dan mengaburkan nilai-nilai Islam. ${ }^{17}$

Perdebatan akut antara pengikut mazhab fiqh menelurkan fanatisme mazhab yang berlanjut pada masa al-Hirawi, namun ketika merunut ke kebelakang menelusuri konstruk epistomologi mazhab antar keduanya, ditemukan perbedaan yang sangat tajam. Juru bicara mazhab hanafi, Abu Yusuf dalam al-kharaj menggunakan hadis dalam tataran dan wilayah yang sempit. Sebab bagi Abu Yusuf, ada perbedaan antara hadis dengan sunnah dan menerima hadis (verbal speaking) ketika tidak bertentangan dengan al-Qur'an dan sunnah baik itu dari rasul maupun generasi setelahnya dari sahabat dan tabi'in. ${ }^{18}$ berbeda halnya dengan pemahaman Syafi'i bahwa sunnah hanya dinisbahkan kepada rasul. ${ }^{19}$

\section{Pemikiran Hadis Mulla Ali al-Qari al-Hirawi}

\section{Hadis Mastur}

Mastur secara etimologis berasal dari isim maf"ul "satara" yang berarti tersembunyi. ${ }^{20}$ Al-Hirawi mendefinisikan hadis mastur sebagai hadis yang diriwayatkan oleh seorang rawi yang belum jelas asal usul adil atau tidaknya. Sedangkan al-Sakhawi mengartikan dengan rawi yang tidak diberitakan sisi jarh dan ta'dil-nya. ${ }^{21}$ Ibnu hajar mengkategorikan riwayat mastur sebagai mardud (tertolak) karena ketidakjelasan periwayat hadis dan mensinonimkan dengan majhul hal (ketidakjelasan hal-ihwal perawi) dan majhul ain (ketidakjelasan perawi suatu hadis), lain halnya dengan Ibn Shalah yang menyamakan mastur dengan majhul hal saja. ${ }^{22}$

Menyikapi riwayat mastur, menuai pro dan kontra. ${ }^{23}$ Mayoritas sarjana hadis menolak hadis yang dalam periwayatannya terdapat rawi mastur dengan prinsip kehatihatian yang berlebihan dalam hadis. Menolak hadis mastur bagi mereka merupakan pilihan tepat dibandingkan menerimanya. Berbeda dengan Abu Hanifah- al-Hirawi menyebutnya dengan al-imam al-a'dzam- dan pengikutnya dari masa ke masa tetap menerima hadis mastur karena manusia pada dasarnya tercipta sebagai orang adil dan tidak fasik sampai terbukti kefasikannya. Mazhab hanafi berdalih dengan ayat و و $)$

\footnotetext{
${ }^{17}$ Ahmad Mahram Syeikh Naji, Manahij Muhaddisin min awa'il al-Qarni al-Hadi Asyara ila Awa'il al-Qarni al-Rabi Asyar al-Hijri dalam Mausuah ulum al-Hadis al-Syarif (cairo: Wizarah alAwqaf, 2007), h. 1013-1014.

${ }^{18}$ Hammadi Zuaib, al-Sunnah baina al-Ushul wa al-Tarikh (Beirut: al-Markaz al-Tsaqafi alArabi, 2005), h. 36.

${ }^{19}$ Hammadi Zuaib, al-Sunnah baina al-Ushul wa al-Tarikh (Beirut: al-Markaz al-Tsaqafi alArabi, 2005), h. 41.

${ }^{20}$ Muhammad Sadiq al-Minsyawi, Qamus Mustalahat al-Hadis al-Nabawi (cairo: Dar alFadhilah, tth), h. 113.

${ }^{21}$ Mulla Ali al-Qari, Syarh Syarh Nukhbat al-Fikri fi Musthalah Ahli al-Atsar (Maktabah Misykat al Islamiyah), h. 52.

${ }^{22}$ Mulla Ali al-Qari, Syarh Syarh Nukhbat al-Fikri fi Musthalah Ahli al-Atsar (Maktabah Misykat al Islamiyah), h. 115.

${ }^{23}$ Ibnu Hajar al-Asqalani, al-Nukat ala Nuzhat al-Nazar fi Tawdihi Nukhbat al-Fikri (Riyadh: Dar Ibn al-Jauzi, 1431 H), h. 124.
} 
sedangkan Ibnu hajar lebih memilih untuk tawaqquf. Ibn Hajar dikritik oleh al-Hirawi dalam posisinya untuk tawaqquf karena tidak menyelesaikan permasalahan dan justru berakibat fatal. Sejatinya menurut al-Hirawi, riwayat mastur terlebih dahulu diteliti hal-ihwal perawi secara maksimal sebab tugas dari ulama adalah ijtihad secara kontinyu. Namun pada pada pencarian maksimal telah dilakukan dan belum diketahui, al-Hirawi lebih condong untuk menerima hadis mastur sebagaimana Abu Hanifah menerima sampai terbukti kecacatan perawinya di kemudian hari. $^{24}$

2. Keniscayaan hadis mursal sebagai sebuah hujjah

Mursal merupakan isim maf'ul dari fi'il "arsala" artinya dilepaskan. Secara terminologis, hadis mursal dimaksudkan dengan suatu hadis yang diriwayatkan oleh seorang tabi'in langsung dari Nabi dengan tidak menyebut nama orang yang menceritakan kepadanya. ${ }^{25}$ Banyak pendapat tentang kebolehan hadis mursal dalam berhujjah. Abu Hanifah, Malik, dan Ahmad berhujjah dengan hadis mursal, sedangkan Imam Syafi'i berpendapat bahwa hadis mursal boleh dijadikan hujjah dengan sarat dibantu hadis lain yang musnad atau hadis mursal lain atau dengan qiyas. ${ }^{26}$

Al-Hirawi menegaskan keniscayaan berhujjah dengan hadis mursal, dalam salah satu statemennya dinyatakan bahwa ulama semestinya berbaik sangka menerima hadis mursal sebab rawi yang jatuh (tidak disebutkan) dalam sanad adalah generasi sahabat. Adapun alasan tidak disebutkan namanya bisa terjadi karena beberapa hal. Salah satunya apabila diriwayatkan dari beberapa sahabat sehingga tidak memungkinkan menyebutkan semuanya, seperti pengakuan Hasan al-Bashri yang tidak menyebutkan nama sahabat karena beliau mendengarnya dari tujuh puluh sahabat. Begitu pula, terkadang nama sahabat tidak disebutkan untuk mengindari fitnah, seperti menyebutkan Ali bin Abi Thalib yang meriwayatkan dari rasul. ${ }^{27}$

Dari pernyataan al-Hirawi di atas dapat disimpulkan bahwa diterimanya hadis mursal oleh mayoritas sarjana hadis karena nama (rawi) yang tidak disebutkan berasal dari generasi sahabat dan keadilan para sahabat telah menjadi konsensus umum bagi ulama. ${ }^{28}$ Namun dalam dekade akhir ini, keadilan sahabat semarak dipertanyakan meningat para sahabat juga manusia biasa yang tak lepas dari kesalahan dan khilaf sebagaimana data-data historis mencatat adanya pelbagai perang saudara, penumpasan nyawa dan tindakan yang seharusnya tidak dilakukan. Amru bin Ubaid al-Mu'tazili berpendapat bahwa para sahabat kesemuanya adil sebelum terjadinya fitnah, akan tetapi

\footnotetext{
${ }^{24}$ Mulla Ali al-Qari, Syarh Syarh Nukhbat al-Fikri fi Musthalah Ahli al-Atsar (Maktabah Misykat al Islamiyah), h. 115-116.

${ }^{25}$ Totok Jumantoro, Kamus Ilmu Hadis (Jakarta: Buah Aksara, 2002), h. 166.

${ }^{26}$ Totok Jumantoro, Kamus Ilmu Hadis (Jakarta: Buah Aksara, 2002), h. 167. Lihat juga Mulla Ali al-Qari, Syarh Syarh Nukhbat al-Fikri fi Musthalah Ahli al-Atsar (Maktabah Misykat al Islamiyah), h. 84. al Islamiyah), h. 84

${ }^{27}$ Mulla Ali al-Qari, Syarh Syarh Nukhbat al-Fikri fi Musthalah Ahli al-Atsar (Maktabah Misykat

${ }^{28}$ Ibnu Hajar al-Asqalani, al-Isabah fi Tamyizi al-Sahabah (Beirut: Dar Kutub Ilmiah, 2002), h. 17.
} 
setelah fitnah, mempertanyakan hadis para sahabat adalah hal yang niscaya. Al-Dzahabi dalam karyanya Siyar A'lam al-Nubala' juga menyatakan 'tadlis al-sahabah katsir wa la aiba fihi". ${ }^{29}$ Sehingga Nampak jelas dari pernyataan di atas bahwa sahabat bukanlah generasi ma'sum yang terjaga dari pelbagai kesalahan dan kekhilafan.

3. Hadis Maudhu'

Secara etimologis, kata maudhu' adalah isim maf'ul dari kata "wadha'a" yang berarti al-isqath (menggugurkan), al-tark (meninggalkan) al-iftira' wa al-ikhtilaq (mengada-ada). Sedangkan secara terminologis, Ibn Shalah yang kemudian diikuti oleh Imam al-Nawawi, mendefenisikan hadis maudhu' sebagai hadis yang diciptakan dan dibuat-buat. $^{30}$

Al-Hirawi mengkategorikan hadis maudhu' ke dalam dua jenis yaitu maudhu' kubra (hadis palsu yang kualitasnya jelas palsu) dan maudhu' sugra (hadis palsu yang kualitasnya ringan). Al-Hirawi mengarang sejumlah kitab terkait dengan hadis maudhu'. Dan salah satunya adalah al-Masnu' fi Ma'rifah al-Hadis al-Maudhu' yang merupakan kumpulan hadis-hadis maudhu' sugra. Dalam pengantarnya yang sangat ringkas dikatakan bahwa al-Hirawi menghindari penyebutan lafaz maudhu' sebab bisa jadi sebuah hadis maudhu' dilihat dari suatu periwayatan dan dalam riwayat yang lain didapati jalur sanad yang sahih, al-Hirawi lebih lanjut menegaskan bahwa hal itu dikarenakan fokus penelitian kesahihan hadis para sarjana muslim terpusat pada sanad. Kategori dua jenis maudhu' menurut asumsi penulis terinspirasi dari pernyataan alZarkasyi dalam pernyataannya 'baina qaulina lam yasih wa qailina maudhu' baunun wadih" yang beliau kutip. Al-hirawi mengartikan maudhu' kubra dengan kejelasan kepalsuan hadis, sedangkan maudhu' sugra dimaksudkan dengan ketidakjelasan asal usul hadis yang bisa saja bersumber dari nabi atau tidak. ${ }^{31}$

Dalam al-Masnu' milik al-Hirawi, tidak dibeberkan penyebab yang memotivasi pemunculan hadis maudhu' namun berkiblat pada Syarh-syarh Nukhbat alFikr mengindikasikan kesamaan pandangan secara umum dengan Ibnu Hajar yaitu (1) usaha kaum zindiq (2) faktor kebodohan tanpa analisis-kritis (3) sikap fanatik buta (4) menjilat penguasa, dan (5) sikap ambisi pada ketenaran. ${ }^{32}$ Al-Hirawi menambahkan usaha kaum munafik sebagai salah satu faktor penyebab munculnya hadis dhaif dengan membedakan kaum zindiq dengan munafik dalam syarahnya. ${ }^{33}$

\section{PENUTUP}

\footnotetext{
${ }^{29}$ Hammadi Zuaib, al-Sunnah baina al-Ushul wa al-Tarikh (Beirut: al-Markaz al-Tsaqafi alArabi, 2005), h. 36.

${ }^{30}$ Muhammad Nor Ichwan, Studi Ilmu Hadis (Yogyakarta: Rasail Media Group, 2007), h. 151.

${ }^{31}$ Mulla Ali al-Qari, al-Masnu' fi Ma'rifah al-Hadis al-Maudhu' tahqiq oleh Abdul Fattah Abu Guddah (Beirut: Dar al-Basyair al-Islamiyah), h. 43-44.

${ }^{32}$ Ibnu Hajar al-Asqalani, al-Nukat ala Nuzhat al-Nazar fi Tawdihi Nukhbat al-Fikri (Riyadh: Dar Ibn al-Jauzi, $1431 \mathrm{H})$, h. 112.

${ }^{33}$ Mulla Ali al-Qari, Syarh Syarh Nukhbat al-Fikri fi Musthalah Ahli al-Atsar (Maktabah Misykat al Islamiyah), h. 95-96.
} 
Al-Hirawi, sosok intelektual ensiklopedis yang menghimpun karya-karya para sarjana muslim klasik sebelumnya yang membuktikan kejeniusannya, bahkan Abdur Rahman Syima' menyebutnya sebagai tokoh yang layak digelari pembaharu pada abadnya. $^{34}$ Namun pembacaan pemikiran al-Hirawi dengan kaca mata abad kontemporer dimana perangkat dan metodologi ilmu pengetahuan telah berkembang pesat, sehingga pemikiran klasik al-Hirawi dengan sendirinya termarjinalkan, terkesan rancu dan ditemukan lahan kritikan, padahal sejatinya seorang ilmuwan lebih didasari pada semangat zaman dan ikatan ruang realitas dimana ia hidup. Sehingga ilmu pengetahuan selalu bersifat situasional dan dinamis mengikuti arah ruang dan waktu.

\section{DAFTAR PUSTAKA}

al-Asqalani, Ibnu Hajar. al-Nukat ala Nuzhat al-Nazar fi Tawdihi Nukhbat al-Fikri. Riyadh: Dar Ibn al-Jauzi, $1431 \mathrm{H}$.

al-Minsyawi, Muhammad Sadiq. Qamus Mustalahat al-Hadis al-Nabawi. Cairo: Dar alFadhilah, t.th.

al-Qari, Mulla Ali. Syarh Syarh Nukhbat al-Fikri fi Musthalah Ahli al-Atsar Maktabah Misykat al Islamiyah.

al-Syima', Muhammad Abdurrahman. Mulla Ali al-Qari: Fihris Muallafatihi wa Ma Kataba Anhu. Dubai: Tsaqafah wa Turats, 1993.

Ichwan, Muhammad Nor. Studi Ilmu Hadis. Yogyakarta: Rasail Media Group, 2007. Jumantoro, Totok. Kamus Ilmu Hadis. Jakarta: Buah Aksara, 2002.

Naji, Ahmad Mahram Syeikh. Manahij Muhaddisin min awa'il al-Qarni al-Hadi Asyara ila Awa'il al-Qarni al-Rabi Asyar al-Hijri dalam Mausuah ulum alHadis al-Syarif. Cairo: Wizarah al-Awqaf, 2007.

Na'urah, Uthman Muhammad. Syekh Mulla Ali al-Qari, di situs www.marifah.net

Qutlai, Khalil Ibrahim al-Imam ali al-Qari wa atsaruhu fi al-Hadis al-Syarif, Vol. II. Makkah: Ummul Qura Press, t.th.

Zuaib, Hammadi. al-Sunnah baina al-Ushul wa al-Tarikh. Beirut: al-Markaz al-Tsaqafi al- Arabi, 2005.

${ }^{34}$ Muhammad Abdurrahman al-Syima', Mulla Ali al-Qari: Fihris Muallafatihi wa Ma Kataba Anhu (Dubai: Tsaqafah wa Turats, 1993), h. 5. 